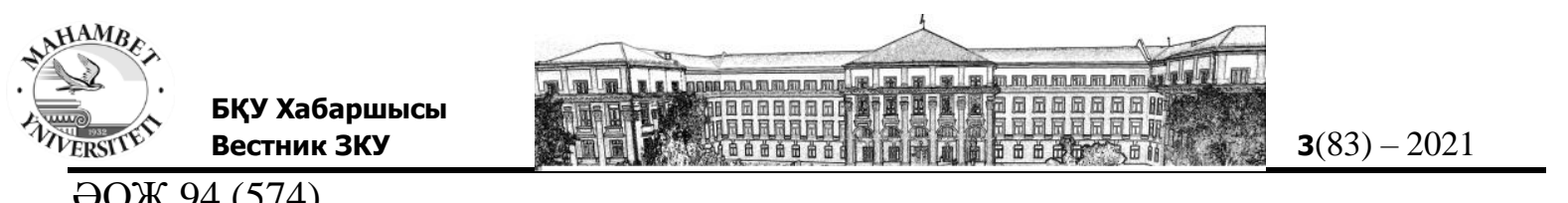

ӘОЖ 94 (574)

FTAXP 03.20

DOI 10.37238/1680-0761.2021.83(3).15

\author{
${ }^{1}$ Сдыков М.Н.*, ${ }^{2}$ Нагиева Б.К. \\ ${ }^{1}$ М.Өтемісов атындағы Батыс Қазақстан университеті, Орал, Қазақстан \\ ${ }^{2}$ А.Тайманов атындағы №34 мектеп-гимназиясы, Орал, Қазақстан \\ *Корреспондент авторы: msdykov@ mail.ru
}

E-mail: msdykov@mail.ru, missnagieva@mail.ru

\title{
ОРАЛ ҚАЛАСЫНДА ҚҰРЫЛҒАН 152-ШІ ДЕРБЕС АТҚЫШТАР БРИГАДАСЫ
}

\begin{abstract}
Аңдатпа. Сталинград шайқ̧асы Ұль Отан совысындавы басты шайқ̧астардың бірі.Сталинград шайқасы мен Батыс Қазақсттанның құрданыс сызызы бар болzаны 200 шақырылды бөліп тұрды.Мақ̆алада Орал құаласында жасақталван 152-ші дербес атқыштар бригадасының совыс барысына елеулі бетбұрыс әкелген Сталинград шайқасына қатысққандывы және 152-атқыштар бригадасының Отан қорвауда өткен айбынды да даңқты жорық жоль және оның ержүрек жауынгерлерінің құан майдандавы жанқиярлық ерліктерібаяндалады. Бригаданың құлыптасуына Мемлекеттік Қорданыс Кеңзесінің қъаулысы және КСРО Қорваныс Халық Комиссариатының 1941 жылzы 20 желтоқсандавы директивасы негіз болван.Автор Сталинград шайқасы барысындавы қорваныс пен қарсы шабуылдар кезінде 152-ші дербес атқышттар бригадасы құрамында шайқасқан жерлестеріміздің құлмақ даласында құасық қ̧аны құлданша құанды шайқасқ̧а түскен жәнеқуаза болван жерлестермен Халхута ауылындавы бауырластар зираты тураль мәліметтер береді.
\end{abstract}

Кілт сөздер: Ұлы Отан совысыл; Орал құаласы; 152- ші дербес атқыштар бригадасы; Сталинград шайқ̧асы; Халхута; шайқ̧ас алаңъы; бауырластар зираты; деректер; естеліктер.

Kipicne

Ғалым - тарихшы, өлкетанушы П.Р.Букатиннің «Боевой путь 152-й отдельной стрелковой бригады - 118-й Мелитополольская краснознаменная Ордена Кутузова II степенистрелковойдивизии», В.П.Скоробогатовтің «28-я в бояхза Калмыкию»,П. С. Беланның «Казахстанцы в битвена Волге» атты еңбектері, архив құжаттары, баспасөз мәліметтері арқылы Оралда жасақталған 152-ші дербес атқыштар бригадасыныңАстрахан бағытындағы қорғаныс ұрыстары, соның ішінде Сталинград қорғанысы мен қарсы шабуылға қатысқан жауынгерлер ерлігін талдау болып отыр.

\section{Зерттеу материалдары мен ддістері}

1942 жылдың жазында соғыстың ең ірі сұрапыл шайқасы Дон мен Еділ арасындағы аумақта жүріп жатты. Гитлерлік әскери басшылық армияның «Б» тобына «Фишрейер» операциясын жүзеге асыруды ұсынып, соның нәтижесінде Сталинградты басып алып, одан Астраханға шығып, Еділдің негізгі арнасындағы әскери қимылдарды тәмамдауға ұмтылды.

Бұл аумақтарды басып алу фашистердің Еділ бойындағы елдің оңтүстігіндегі негізгі көлік артериясы бақылауына алып келер еді. Өйткені, Еділ бойымен Қазақстаннан бидай, Бакуден мұнай, Донбасстан көмір әкелінді. Төменгі Еділ аймағын басып алудың неміс жоспары «Фишрейер»деп аталды[1, б.175 ].

Ұлы Отан соғысы кезінде Хулхута ауданында қызу шайқастар болды. Астрахань бағытындағы «А» армия тобының неміс әскерлерінің жазғы шабуылы кезінде 1942 жылы 28 
тамызда Вермахттың 16-шы моторлы дивизиясы, құрамында екі моторлы полк, артиллерия полкі және 116-шы танк батальонының 53 танкі Яшкул аймағында шабуылға шықты, нәтижесінде 1942 жылы 31 тамызда Хулхутаны немістерді басып алды. Ол бүкіл кеңесгерман майданында неміс әскерлері басып алған ең Шығыс нүкте болды.

1942 жылы 31 тамызда Сталинград майданының құрамында Жоғарғы Бас қолбасшылық ставкасының резервтерімен күшейтілген Сталинград әскери округінің бөлімшелерінен 28-ші армия құрылды. Оның қолбасшы - генерал-лейтенант В.Ф. Герасименко, армия бөліктері хулхута-Юста- Ракотаевская станциясы ауылдарының желісінде неміс - румын әскерлерінің алға жылжуын тоқтатты. Кейін Хулхута ауданында майдан сызығы тұрақтанды[2, б.231].

28-ші армияның құрамына Хулхута аймағында қорғаныс шайқастарын жүргізетін кеңестік бөлімдер мен бөлімшелер кірді.Оның құрамына Орал қаласында жасақталған 152-ші дербес атқыштар бригадасы да кірді.Командирі - полковник Рогаткин, комиссары С.Мартынов. 152-ші дербес атқыштар бригадасы құрамына Алматы, Ақтөбе, Гурьев, Қызылорда және тағы да басқа облысыстар мен өңірлерден алынған жауынгерлер құрады[3].

152-ші дербес атқыштар бригадасы мен 34 гвардиялық атқыштар дивизиясы Астархань қаласы маңы ұрысында және қалмақ даласында жауды жеңуде шешуші рөль атқарды.

1942 жылы 2 қыркүйекте Сталинград әскери округ №6 бұйрығы бойынша 152-ші дербес атқыштар бригадасына, 107-ші атқыштар полкінежәне 565-ші танк батальонына Халхута ауданына шығып, жауды қоршап жоюды тапсырды[4, б.499].

Бұл ұрыста ерекше батылдық көрсеткен комсомол, артиллерист А.Жамалов және қару-жарақ командирі, кіші сержанттар Михайлов пен Пестриковтар айрықша көзге түсті. Мергендігімен ерекше танылған олар 4 неміс танкісін істен шығарды, содан кейін өздерінің танкистерімен бірге дұшпан батареясының оқ атқылауын тоқтатты және бірнеше оқ ату нысандарын жойды. Ұрыстар барысында шығындар да болды. Капитан Панинніңқолжазбасы Ресей архивінде сақтаулы. Соның ішінен қаза тапқан, хабарсыз кеткендер тізімінде Батыс Қазақстан облысынан Орал қаласы, Тасқала, Орда, Чапай және тағы да басқа аудандардан алынған 30 жауынгердің есімдерін анықтап отырмыз[5].

Неміс-фашистерден тартып алынған окоптардың бірінен минометті ротаның саяси жетекшісі, жаудың танкілік десантімен батыл бетпе-бет айқасып, ауыр жараланған И.Я.Зиновьевтің мүрдесінің қалдықтары табылды. «Фашистік хайуандар қолынан өртеліп, қаза болған саяси жетекшіні еске алуға арналған митингіде командирлер мен солдаттар жаудан аса қатыгездікпен кек қайтаратындығына ант берді»- деп баяндайды «Правда» газеті [6, б. 60].

5 күн ішінде жаудың 400 солдаты мен офицерлерінің, 18 танкісі мен 6 брондалған машинанысының көзін жойып, жауынгер жолдастарының қазасы үшін берілген антты бригада жауынгерлері абыроймен орындады.

Бригада артиллеристері жаудың 2 артиллериялық және 3 минометтік батареясын істен шығарды. Коммунист И.Сипаловтың басшылығымен жасалған танкіге қарсы қарудың тиімді расчетпен құрылуы оларға батыл іс-қимыл жасауға мүмкіндік берді.

Артиллеристер М.М.Гоглачев, С.Г.Баранов, Ш.Каримов, Л.В.Бакшиев, П.Рябоконьдар майдан даласындағы жау танкілерін ата бастайды. Әскери ұрыс кезінде 4 гитлерлік танкіні жойған батыр И.Сипалов ерлік жасап қаза табады[7, б 52].

Қыркүйектің 23-нен 24-не қараған түнінде 2 атқыштар және минометті батальон шабуылға шықты, жаудың күшті қарсылығына қарамастан оларға тойтарыс беріп қана қоймай, окоптардың бірінші шебін басып өтіп, Хулхута етегіне бекініп үлгерді. Бұл соғыста кіші сержант В.Макатченконың минометшілер расчеті қайсарлық пен батылдық танытып 180 гитлершілерді, 4 миномет, 3 станкілі пулеметті жойды және 7 пулеметтің ұяшықтары талқандайды. 
Жаудың Астраханды оңай жаулап аламыз деген жоспары осылай күйреді. Азамат соғысының ардагерлері 1942 жылдың 4 қарашасында Астрахан қалалық комитеті және Қалмақ обкомпартиясы, Совнарком мен Қалмақ АКСР-і Жоғары Кеңесі Президиумы қалаға қиыр шығыстан кіру үшін болған ұрысқа белсенді қатысқаны үшін бригаданы Қызыл Тумен марапаттады және бригада жауынгерлеріне Астрахан қаласына жауды кіргізбеуді, Калмыкиядан неміс басқыншыларын қуып шығуды тапсырды.

1942 жылдың 20 қарашасында таңда бригада бөлімшелері шабуылды бастап, жаудың салып қойған қорғаныстарын айналып өтіп, тез арада күшейтілген Сян-Цик пункітін өздеріне қаратады. Хулхуттаны Элистамен байланыстыратын жолды кесіп тастайды.

Батыс Қазақстан облысы Приуралье ауданының Красновский ауылының тумасы, танкіге қарсы қарудың (ПТР) мергені ефрейтор Н.Курмаевтың ұрыста атқыштардың ісқимылына кедергі келтіріп отырған жаудың станкілі пулеметін шеберлікпен жойған[8 ].

Калмыкияны азат ету кезіндегі ұрыста өз бөлімінен тыс жерде, роталық комсомол ұйымының хатшысы, Қазақстаннан шыққан сержант Исса Айтановтың батырлығы мәлім болды. Ол Сталинград майданында мергендер қозғалысының ұйымдастырушысы болған. 26 немістің көзін жойған.Ол жауды тек снайперлік винтовка емес басқа да қару көмегімен жоюға болатындығын көрсетті.(Сур.1).

Шабуылдаушы 28-ші армияның құрамында болған бригаданың сәтті жүргізілген әскери қимылдарының нәтижесінде жаудың Яшкульдегі күшті қорғалған тірек пункітіндегі немістердің моторлы дивизиясына жойқын соққы берілді. Осының нәтижесінде майдандағы басқа армияларға қосымша көмек келіп, Сталинградтағы Паулюс армиясын қоршауды аяқтауға мүмкіндік туды. Сонымен қатар бұл жағдай сыртқы майданның жасақталуына да әсер етті[9].

1942 жылдың 31 желтоқсанында солтүстіктен орап өту маневры арқылы бригада жауынгерлері қалмақ халқына берілген анттарын абыроймен орындады. Олар Элистаны жаудан азат етті. Қаңтардың ортасына қарай Маньч өзеніне шықты, ал 22 қаңтарда басқыншыларды Сальскіден қуды. 8 ақпанға қараған түні 152-дербес атқыштар бригада жауынгерлері мен офицерлері алғашқылардың бірі болып Дондағы Ростовқа қарай шабуылға шықты.

Қазақстандық 152-атқыштар бригадасымен болған ұрыстарда 2 мыңнан астам солдаттары мен офицерінен және 18 танкісінен айырылған жау Астраханьға шабуыл жасау әрекетінен бас тартты.

1943 жылғы майдың аяғында аз уақытқа орнаған тыныштық кезінде бригада резервке шығарылып, Ростов облысының Мясников ауданының Ленинаванселосына жеткенде бригада өз қатарын толықтырып,118-атқыштар дивизиясы болып қайта құрылды[10, б.22].

\section{Қорытындысы}

Оралда құрылған 152-ші дербес атқыштар бригадасының Ұлы Отан соғысы барысындағы ерлік жолы туралы мақалалар мен зерттеулер аз жазылғанымен оның ержүрек жауынгерлерінің қан майдандағы ержүрек ерліктері мұрағат деректері мен тарих парақтарында осылай сайрап жатыр. Отан қорғау жолында қасық қаны қалғанша қиян кескен ұрыс жүргізіп, қан майданда қаза тапқан оғландарды жас ұрпақ әруақытта естен шығармас.

Ұлы Отан соғысы кезінде шайқаста қаза тапқан 28-ші армияның жауынгерлеріне арналған Халхута ауылында бауырластар зираты бар. Ескерткіш 1982 жылы орнатылған. Мемориал авторлары-сәулетшілер Н.Х. Бораев, С. Е. Курнеев, В. Б. Гирляндиков, Э. Е. Лиди-Горяев, М. Б. Пюрвеев. 2009 жылы мемориалдық кешен Қалмақ Республикасының мәдени мұра объектілерінің тізіміне енгізілген. (№254).(Сур.2) 

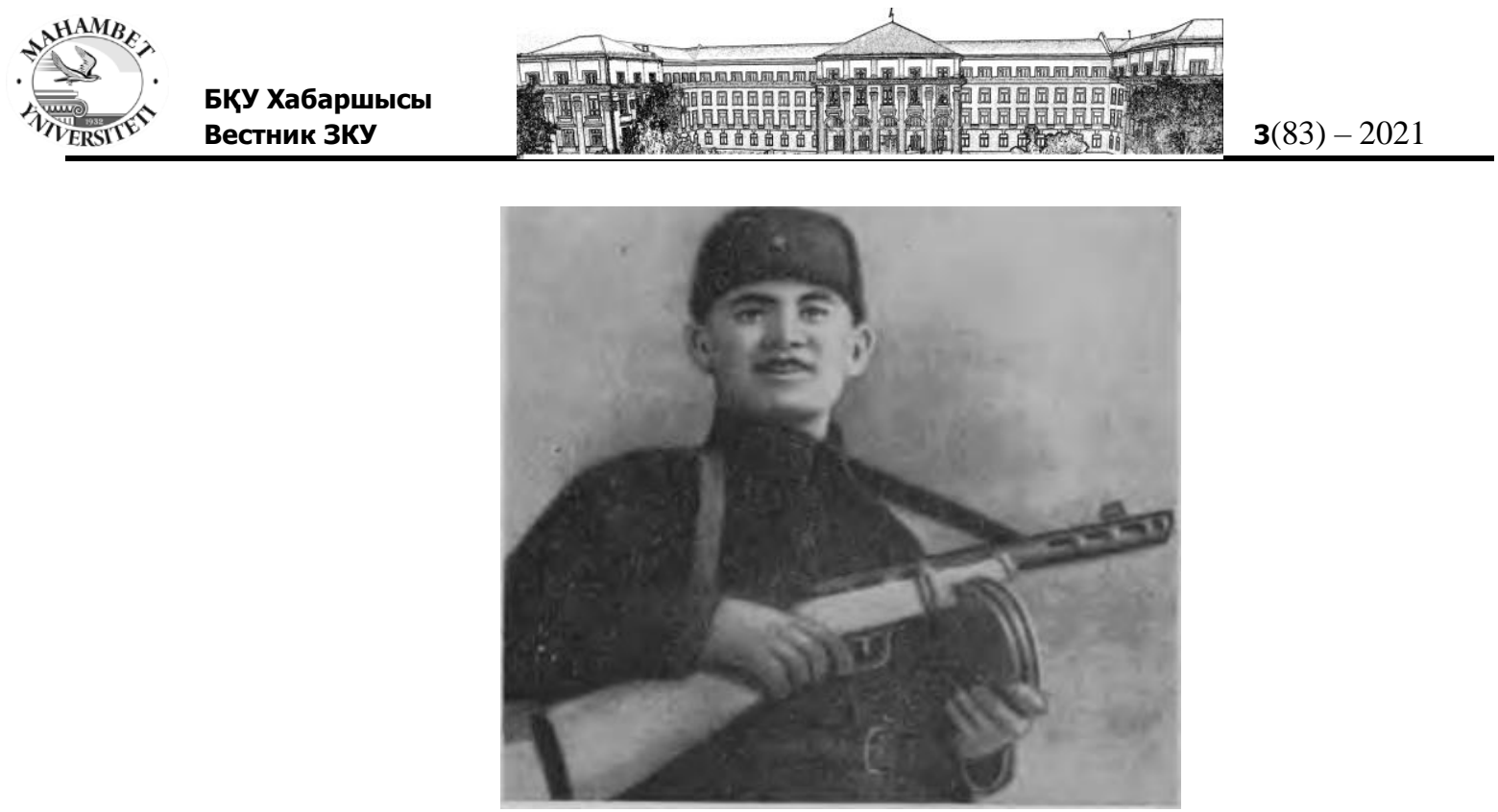

1-сурет. 152-атқ̧ьишатр бригадасының жауынгері Исса Айтанов.

Ол туралы «Красное знамя» газетінде былай деп жазылған: «үш шайқаста 26 басқыншыны жойған батыл сержант Исса Айтановты Қызыл Армия мақтан тұтады».

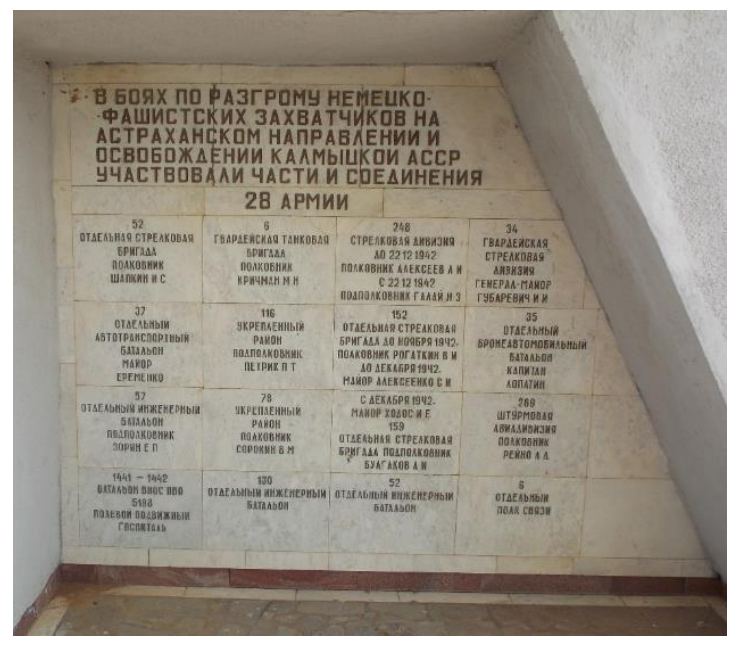

2-сурет. Бауьирластар зиратьл

Ескерткіш орналасқан аумақта неміс әскерлерінің Астраханға қарай жылжуы тоқтатылды. 28-ші Армия жауынгерлеріне арналған мемориалдық кешен-Қалмақ Республикасы Яшкуль ауданы Хулхута елді мекенінен шамамен 2 шақырым жерде А154 жолында орналасқан.

\section{ӘДЕБИЕТ}

[1] "Великая Отечественная война Советского Союза.1941-1945». Қысққаша тарих. Воениздат, Мәскеу, 1984ж. [Электрондық ресурс]. - Қол жеткізу режимі http://militera.lib.ru/h/gpwshl/index.html/

[2] М. М. Козлова «Двадичать восьмая армия» // Великая Отечественная война, 1941 1945: энщиклопедия //. Москва: 1985.- 231-бет

[3] РФ ҚМОА жеткізу көзінің атауыл. Ақ̧парат көзі ққорының нөмірі 58. Ақ̧парат көзі тізімдемесінің нөмірі 18001. Ақ̧парат көзі ісінің нөмірі 1265. [Электронный ресурс]. - Қол жеткізу режимі (http://www.obd-memorial.ru/html/index.html). 
[4] К.К.Рокоссовского «Великая победа на Волге» / К.К.Рокоссовского. - М., 1965 , бет. 499; РФ КМОА, ф. 1324, оп. 1, д.1.

[5] «Выписка из журнала боевых действий 152 осбр» Сипаттайды кезен 26.08.1942 24.10 .1942 ж. әскери құимылдар Журнальы. Құжаттың жасалzан күні: 24.10.1942 ж. Мұрават: РФ ҚМОА, Қор: 442, тізімдеме: 8465, іс: 14-1, істегі құжаттың басталу паравы: 1 Құжат авторлары: 152 осбр, Капитан Панин.

[6]. В.П.Скоробогатовтің «28-я в боях за Калмыкию» / В.П.Скоробогатов. Элиста, 1968, 60 бет.

[7] В. П. Скоробогатовтың «28 $\rightarrow$ в боях за Калмыкию» / В.П.Скоробогатов. Элиста, 1968, 52-бет.

[8] П. Р. Букаткин «На левом фланге Сталингардского фронта» / П. Р. Букаткин// "Приуралье", №19. 05.02.1993ж

[9] К.К.Рокоссовского «Великая победа на Волге» /К.К.Рокоссовско. - Москва, 1965, 293-бет.

[10] П. Р. Букаткин "От Уральска до Эльбы и Праги" / П. Р. Букаткин. - Уральск 1994ж, 22-бет.

\section{REFERENCES}

[1] Velikaia Oteşestvennaia voina Sovetskogo Soiuza.1941-1945 (1984) [The Great Patriotic War of the Soviet Union. 1941-1945]. Qysqaşa tarih. Voenizdat, Mäskeu, Retrieved from http://militera.lib.ru/h/gpwshl/index.html/ [in Kazakh].

[2] Kozlova M. M. (1985) Dvadsat vosmaia armia // Velikaia Oteşestvennaia voina, 1941 1945 [Twenty-eighth Army // The Great Patriotic War, 1941-1945] Moskva [in Russian].

[3]. RF QMOA jetkızu közınıñ atauy. Aqparat közı qorynyñ nömırı 58. Aqparat közı tızımdemesiniñ nömirl 18001. Aqparat közl usiniñ nömır 1265 [Name of the source of delivery of the Central Archive of the Ministry of Defense of the Russian Federation] Retrieved from http://www.obd-memorial.ru/html/index.html [in Kazakh].

[4]. Rokosovski K.K. (1965) Velikaia pobeda na Volge [The Great Victory on the Volga] Moscow. [in Russian].

[5]. Osbr 152 soǵys jýrnalynan úzindi 26.08.1942 jyldan 24.10.1942 jylǵa deningi kezeńdi sipattaldy. Qujattyń jasalǵan kúni: 24.10.1942 j. Muraǵat: SAMO, Qor: 442, tizimdeme: 8465, is: 14-1, istegi qujattyń bastapqy paraǵy: 1 Qujat avtorlary: 152 osbr, Kapıtan Panın [Extract from the combat log 152 OSBR] [in Kazakh].

[6]. Skorobogatov V. P. (1968), Qalmaqua úshin shalqastarda 28 -shi [28th in the battles for Kalmykia] - 60, Elista. [in Russian].

[7]. Skorobogatov V. P. (1968), Qalmaqua úshin shalqastarda 28 -shi [28th in the battles for Kalmykia] - 52, Elista. [in Russian].

[8]. Býkatkın P. R. (1993) Stalıngard maldanynyn sol qaptalynda [On the left flank of the Stalingard Front], 19, Oral mańy [in Russian].

[9]. Rokossovskı K. K. (1965). Edildegi Uly Jeńis [The Great Victory on the Volga] Máskeý [in Russian].

[10]. Býkatkın P. R. (1994) Oraldan Elba men Pragaǵa deiin [From Uralsk to Elba and Prague] Oral [in Russian].

\section{Сдыков М.Н., Нагиева Б.К. \\ 152-Я ОТДЕЛЬНАЯСТРЕЛКОВАЯ БРИГАДА, СФОРМИРОВАННАЯ В Г. УРАЛЬСКЕ}

Аннотация.Сталинградская битва-одно из главных сражений в Великой Отечественной войне. Линия обороны Сталинградской битвы и Западного Казахстана разделяла всего 200 километров. В статье рассказывается об участии 152-й отдельной стрелковой бригады, сформированной в Уральске,и о доблестном и славном походе 152-й 


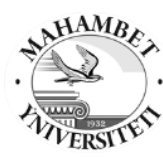

стрелковой бригады на защиту Отечества и о самоотверженном подвиге ее отважных воинов на кровавом фронте.Основанием для формирования бригады послужило постановление Государственного Совета обороны и директива Народного Комиссариата Обороны СССР от 20 декабря 1941 года. Автор дает сведения о братских могилах селе Халхута, погибших и вступивших в кровопролитную битву на калмыцких степях наших земляков, сражавшихся в составе 152-й отдельной стрелковой бригады в период обороны и контрнаступления в ходе Сталинградской битвы.

Ключевые слова: Великая Отечественная война; г.Уральск; 152-я стрелковая бригада; Сталинградская битва; Халхута; поля битвы, братские могилы, источники, воспоминания.

\section{Sdykov M. N., Nagieva B. K.}

\section{ND RIFLE BRIGADE, FORMED IN URALSK}

Annotation.The Battle of Stalingrad is one of the main battles in the Great Patriotic War.

The line of defense of the Battle of Stalingrad and Western Kazakhstan was separated by only 200 kilometers. The article tells about the participation of the 152nd Rifle Brigade, formed in Uralsk, in the Battle of Stalingrad, which brought a significant turn in the course of World War II, about the valiant and glorious campaign of the 152nd Rifle Brigade to defend the Fatherland and about the selfless feat of its brave soldiers on the bloody front. In general, the basis for the formation of the brigade was the resolution of the State Defense Council and the directive of the People's Commissariat of Defense of the USSR of December 20, 1941. Grave graves and mass graves in the village of Khalkhuta, who died and fought in the bloody battle on the Kalmyk steppes of our countrymen, who fought as part of the 152nd Rifle Brigade during the defense and counteroffensive during the Battle of Stalingrad.

Keywords: The Great Patriotic War; Uralsk; 152-I Rifle Brigade; The Battle of Stalingrad; Khalkhuta; battlefields, mass graves, sources, memories. 